\title{
Nitroxide Stable Radicals Protect Beating Cardiomyocytes against Oxidative Damage
}

Amram Samuni," Dorit Winkelsberg, * Ariè Pinson," Stephen M. Hahn," James B. Mitchell," and Angelo Russo* Departments of *Molecular Biology and ${ }^{\ddagger}$ Biochemistry, School of Medicine, Hebrew University, Jerusalem, 91010, Israel; and ${ }^{\$}$ Radiation Oncology Branch, National Cancer Institute, National Institutes of Health, Bethesda, Maryland 20892

\begin{abstract}
The protective effect of stable nitroxide radicals against oxidative damage was studied using cardiomyocyte cultures obtained from newborn rats. Monolayered cardiomyocytes were exposed to $\mathrm{H}_{2} \mathrm{O}_{2}$ and the effect on spontaneous beating and leakage of LDH was determined. Hydrogen peroxide irreversibly blocked rhythmic beating and resulted in a significant membrane injury as shown by release of $\mathrm{LDH}$. The injury was prevented by catalase which removes $\mathrm{H}_{2} \mathrm{O}_{2}$ and by cell-permeable, metal-chelating agents such as desferrioxamine or bipyridine. In contrast, reagents which are excluded from the cell such as superoxide dismutase or DTPA did not protect the cells against $\mathrm{H}_{2} \mathrm{O}_{2}$. Five- and six-membered ring, stable nitroxide radicals which have previously been shown to chemically act as low-molecular weight, membrane-permeable, SOD-mimetic compounds provided full protection. The nitroxides prevented leakage of LDH and preserved normal cardiomyocyte contractility, presumably by intercepting intracellular $\mathrm{O} \dot{2}$ radicals. Alternatively, protection may result through nitroxides reacting with reduced transition metal ions or by detoxifying secondary organic radicals. ( $J$. Clin. Invest. 1991. 87:1526-1530.) Key words: rat heart cells • superoxide radical $\bullet$ nitroxide spin-labels
\end{abstract}

\section{Introduction}

Oxidative damage and postischemic reperfusion injury, in particular, have been recently the focus of intensive research (1-3). The extension of primary ischemic injury results from reperfusion and is caused largely by oxygen-derived reactive species both from intra- and extracellular sources. A variety of pathological conditions have been linked to the formation of superoxide and secondary free radical and nonradical reactive products (1-3). Efforts were made, therefore, to attenuate the reperfusion component of ischemia/reperfusion myocardiac damage at several levels: $(a)$ decreasing $\mathrm{O} \div$ formation, using specific xanthine oxidase inhibitors such as allopurinol or oxypurinol (4-7); (b) detoxifying $\mathrm{O} \div$ by employing superoxide dismutase or agents possessing SOD-mimicking activity (6-9); (c) removing, by chelating agents, redox-active metals that fuel toxic cycles $(9,10) ;(d)$ decreasing the level of $\mathrm{H}_{2} \mathrm{O}_{2}$ with catalase or GSH-peroxidase $(6,9,11) ;(e)$ scavenging free radicals,

Address correspondence to Stephen M. Hahn, M.D., Radiation Oncology Branch, National Cancer Institute, Building 10, Room B3 B69, National Institutes of Health, 9000 Rockville Pike, Bethesda, MD 20892.

Received for publication 13 June 1990 and in revised form 10 September 1990.

The Journal of Clinical Investigation, Inc.

Volume 87, May 1991, 1526-1530 using various antioxidants, and thereby terminating radical chain reactions $(6)$.

Very recently five- and six-membered stable nitroxides which are commonly used as probes in biophysical studies (12, 13) and as nuclear magnetic resonance imaging contrast agents (14) were found to undergo facile redox reactions and to catalyze effectively $\mathrm{O}-\dot{2}$ dismutation $(15,16)$. Moreover, nitroxides were shown to oxidize coordinated transition metals that are known to mediate and potentiate free radical-induced damage (17). Subsequent studies demonstrated that nitroxides inhibit lipid peroxidation (18) and protect against $\mathrm{H}_{2} \mathrm{O}_{2}$-induced cytotoxicity to Chinese hamster cells, and suggested that nitroxide protection results from oxidizing reduced transition metals $(17,19)$. In the present work, myocardial cells isolated from newborn rats were exposed to $\mathrm{H}_{2} \mathrm{O}_{2}$ to provide a cellular model system to examine if there may be a role for stable nitroxides in preventing ischemia/reperfusion injury. The loss of cell contractility and the release of lactate dehydrogenase served as markers of $\mathrm{H}_{2} \mathrm{O}_{2}$-induced oxidative damage. The results suggest that the myocardial damage is catalyzed by intracellular redox-active metals and that nitroxides can effectively provide protection against such injury.

\section{Methods}

Materials. Desferrioxamine (desferral, DFO) ${ }^{1}$ was a gift from CibaGeigy Corp., Ardsley, NY, superoxide dismutase, bipyridine, neocuproine, and diethylenetriamine-pentaacetate (DTPA) were obtained from Sigma Chemical Co., St. Louis, MO; 2-spirocyclohexane-5,5-dimethyl-3-oxazolidinoxyl (compound II), 2,2,6,6-tetramethyl-piperidinoxyl (Tempo), 4-hydroxy-2,2,6,6-tetramethyl-piperidinoxyl (Tempol), and 4-amino-2,2,6,6-tetramethyl-piperidinoxyl (Tempamine) were purchased from Aldrich Chemical Co., Milwaukee, WI, and $\mathrm{H}_{2} \mathrm{O}_{2}$ from E. Merck, Darmstadt, FRG. All other chemicals were prepared and used without further purification.

Nitroxide synthesis. 2-Ethyl-2,5,5-trimethyl-3-oxazolidinoxyl was synthesized as previously described (20). Briefly, to produce the amine, 2-butanol was reacted with 2-amino-2-methyl-1-propanol in benzene using $p$-toluene sulfonic acid catalysis. The formation of the cyclic structure resulted in the elimination of water. The volume of water collected in a Dean-Stark apparatus was monitored and used to gauge the reaction progress. The amine thus produced was purified through fractional distillation under reduced pressure, characterized by means of NMR, IR, UV, mass spectroscopy, oxidized to the corresponding

1. Abbreviations used in this paper: compound I, 2-ethyl-2,5,5-trimethyl-3-oxazolidinoxyl; compound II, 2-spirocyclohexane doxyl (2cyclohexane-5,5-dimethyl-3-oxazolidinoxyl); DFO, desferrioxamine; DTPA, diethylene-triamine-pentaacetate; EPR, electron paramagnetic resonance; $\mathrm{LDH}$, lactate dehydrogenase; PCA, 3-carboxy-2,2,5,5-tetramethylproxyl; tempamine, 4-amino-2,2,6,6-tetramethyl-piperidinoxyl; tempo, 2,2,6,6-tetramethyl-piperidinoxyl; tempol, 4-hydroxy2,2,6,6-tetramethyl-piperidinoxyl; SOD, superoxide dismutase. 
nitroxide using $m$-chloroperbenzoic acid, and purified by silica flash chromatography.

Electron paramagnetic resonance. EPR spectra were recorded using a E4 X-band spectrometer (Varian Associates, Inc., Palo Alto, CA), with field set at $3,357 \mathrm{G}$, modulation frequency of $100 \mathrm{kHz}$, modulation amplitude of $1 \mathrm{G}$, and nonsaturating microwave power as described previously (17).

Culture preparation. Ham F-10 culture medium (Beth Ha'emek, Israel) supplemented with $\mathrm{CaCl}_{2} \cdot \mathrm{H}_{2} \mathrm{O} 135 \mathrm{mg} /$ liter, penicillin $200 \mathrm{U} /$ $\mathrm{ml}$, streptomycin $0.2 \mu \mathrm{g} / \mathrm{ml}, 10 \%$ horse serum, and 10\% FBS (Gibco, Grand Island, NY) was used as the growth medium. For mincing and washing the organs and for trypsinization, solution $\mathrm{H}$ defined as Ham F-10 without calcium or magnesium was used. Trypsin (type III; Sigma Chemical Co.) was dissolved in $0.1 \% \mathrm{wt} / \mathrm{vol}$ solution $\mathrm{H}$. Ascorbic acid (Cereon; Assia, Ramat Gan, Israel) and $\alpha$-tocopherol (Ephymal; Hoffman-La Roche, Nutley, NJ) were both used at concentrations of 1 $\mathrm{mg} / \mathrm{ml}$.

Cultures from 1-d-old rats (Hebrew University strain) were obtained by a slight modification of previously published methods (21) The newborn rats were killed by decapitation. Hearts were removed aseptically, retaining the ventricles only. The excised hearts were placed in a Petri dish containing solution $\mathrm{H}$. The organs were minced into very small fragments and washed twice during mincing. Solution $\mathrm{H}$ was then replaced by trypsin solution and transferred to a $25-\mathrm{ml}$ flask. The volume of trypsin solution was $10-15 \mathrm{ml}$ for 30-50 hearts. Trypsinization was performed at $32^{\circ} \mathrm{C}$ with a stirring rate of $150-200$ rpm for 15-20 min. At the end of each trypsinization, fragments were allowed to settle, the supernatant removed, and another portion of trypsin was added. Supernatants from the first two to three trypsinizations, which contained mostly cell debris, red blood cells, and pericardial endothelial cells, were discarded. Cells from subsequent trypsinizations were collected in 30-ml sterile tubes. A few milliliters of growth medium were added to stop the trypsin digestion, and cells were centrifuged at $1,000 \mathrm{rpm}$. The pellet was resuspended in a small volume of growth medium. Each trypsinization cycle was repeated until all fragments were dissociated.

Cell cultures. Cells from each tube were resuspended by repeated aspiration into a sterile pipette, and all fractions were combined into a sterile 250-ml flask (Nunc; Nunclon Delta, Herlev, Denmark) after filtering through a sterile mesh to exclude explants. 20-25 neonatal rat hearts yielded $50-60$ million cells with a viability of $90 \pm 5 \%$ as measured by Trypan blue exclusion. The pooled cells were diluted in growth medium to a density of $10^{6}$ cells $/ \mathrm{ml}$ and seeded into $35-\mathrm{mm}$ diameter Petri dish (Falcon 3001; Falcon Labware, Oxnard, CA). After seeding, Petri dishes were gently shaken horizontally to obtain a uniform distribution of cells. This concentration yielded after 24-36 h, when the cells had sufficient cytoplasmic extensions to make contact with other cells, an almost confluent layer at a final density of $\sim 2$ $\times 10^{5}$ cells $/ \mathrm{cm}^{2}$. Cultures were kept at $37^{\circ} \mathrm{C}$ in an atmosphere of $5 \%$ $\mathrm{CO}_{2}$ and $95 \%$ air. The $\mathrm{pH}$ of cultures was maintained at $7.4 \pm 0.05$. The cells at the time of isolation were rounded with an average diameter of $2-5 \mu \mathrm{m}$. At a plating density of $4-8 \times 10^{4} \mathrm{cells} / \mathrm{cm}^{2}$, a plating efficiency of $70 \pm 5 \%$ was obtained as determined by the number of cells that became attached within 10-12 h. The attached myocytes were flat and had an irregular star shape with an average width of $20 \pm 5 \mu \mathrm{m}$. About $80-85 \%$ of the cells were beating at various rates ranging from 60 to 150 beats/min. After $72 \mathrm{~h}$ in culture, their rhythmic and synchronous beating stabilized at $140-150$ beats $/ \mathrm{min}$. The beating rate slowed down slightly by the eighth day in culture. Experiments were performed at $5 \mathrm{~d}$ when $>80 \%$ of the cells that were present on the plate were beating myocardial cells. Continued viability of cultured cells was documented by Trypan blue exclusion and by the absence of leakage of enzyme (lactate dehydrogenase) into the culture medium.

Contractility. The rhythmic pulsation of the cultures was followed using an Olympus inverted phase microscope before and after each treatment. The culture dishes were removed from the incubator, equilibrated for 5-10 $\mathrm{min}$ in a water-jacketed thermostatic cell $\left(37^{\circ} \mathrm{C}\right)$, and the contraction was determined. Generally the $\mathrm{H}_{2} \mathrm{O}_{2}$-induced damage as well as the protection by nitroxide or chelators appeared as an "all or none" effect, i.e., all the cells were either unaffected or fully stopped beating. In specific cases, however, under marginal conditions with insufficient concentration of $\mathrm{H}_{2} \mathrm{O}_{2}$ or nitroxide, a partial effect was observed where only several cells continued to contract. To demonstrate this effect, a "beating microscope field" was defined as $25 \%$ of the visual filed at magnification 200 in which several or at least a single spontaneously beating cell was observed. The use of a beating microscopic field as applied to contacting cardiomyocytes provides a means to assess rapidly the effect of oxidative stress which does not result in complete abrogation of contraction by the entire cell population. Within any given experiment all observations were made in triplicate, and depending upon the number of determinations to be assessed at a given time point, between 5-40 microscopic fields were visualized.

Lactate dehydrogenase $(L D H)$ release. With each medium change, the old medium was collected and assayed for LDH activity (22). In short, a $0.1-\mathrm{ml} \mathrm{sample} \mathrm{was} \mathrm{added} \mathrm{to} 0.9 \mathrm{ml}$ of a solution containing 50 $\mathrm{mM}$ phosphate buffer, $\mathrm{pH} 7.5,0.6 \mathrm{mM}$ pyruvate, and $0.18 \mathrm{mM} \mathrm{NADH}$ (final concentrations). The decrease in $\mathrm{A}_{340}$ was followed for $3 \mathrm{~min}$ at $30^{\circ} \mathrm{C}$, using a dual-beam Uvikon 860 spectrophotometer (Kontron, Switzerland), and the enzyme activity was calculated. To determine the total cellular LDH, the cells were disrupted by sonication or blending and medium was assayed for LDH activity.

\section{Results}

Oxidative damage. Injury was induced by incubating the cultured beating cardiac myocytes on the fifth day after plating with various concentrations of $\mathrm{H}_{2} \mathrm{O}_{2}$, the beating rate was followed microscopically and the medium was assayed for LDH activity. The rate of cell beating rapidly subsided and, within a few minutes, beating irreversibly ceased. Fig. 1 demonstrates a typical effect induced by $250 \mu \mathrm{M} \mathrm{H}_{2} \mathrm{O}_{2}$. Superoxide dismutase (70-350 U/ml) did not protect the cells against $\mathrm{H}_{2} \mathrm{O}_{2}$. Moreover, cell contractility could not be restored by adding catalase or by changing to $\mathrm{H}_{2} \mathrm{O}_{2}$-free medium.

Effect of chelators. To determine whether the damage induced by $\mathrm{H}_{2} \mathrm{O}_{2}$ is catalyzed by transition metals, the cells were incubated with DFO at concentrations previously shown to bind cellular iron (21). DFO $(0.1 \mathrm{mM})$ protected the cells, however, its protective effect was not fully manifested unless long enough preincubation time has allowed for DFO to cross into the intracellular space (Fig. 2). Similar protection was observed when the cultures were incubated with $0.1 \mathrm{mM}$ bipyridine 30 min before adding $\mathrm{H}_{2} \mathrm{O}_{2}$ (data not shown). In contrast, no pro-

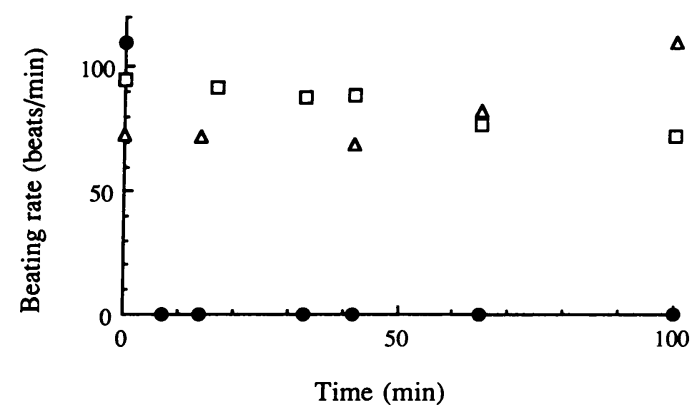

Figure 1. Effect of nitroxides on $\mathrm{H}_{2} \mathrm{O}_{2}$-induced loss of cell contractility. The beating rate of isolated rat heart cells after the incubation with $250 \mu \mathrm{M} \mathrm{H}_{2} \mathrm{O}_{2}$ in the absence (circles) and the presence of (triangles) of $0.5 \mathrm{mM}$ compound II or (squares) of $0.5 \mathrm{mM}$ Tempo. The plated cells were kept at $37^{\circ} \mathrm{C}$ in $\mathrm{Ham}$ F-10 culture medium under atmosphere of $5 \% \mathrm{CO}_{2}$ and $95 \%$ air. 


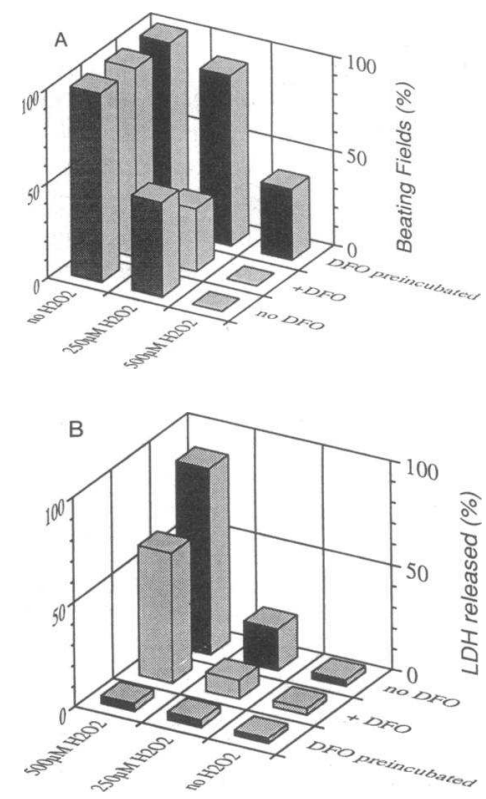

Figure 2. Effect of DFO on $\mathrm{H}_{2} \mathrm{O}_{2}$-induced loss of cellular LDH and contractility of cardiomyocytes. Varying concentrations of $\mathrm{H}_{2} \mathrm{O}_{2}$ were incubated for $80 \mathrm{~min}$ with monolayered beating cardiomyocytes. The effect of $0.1 \mathrm{mM} \mathrm{DFO}$, either preincubated with the cells for $\mathbf{2} \mathrm{h}$ or added together with $\mathrm{H}_{2} \mathrm{O}_{2}$, was studied by determining the residual fraction of "beating microscopic fields" $(A)$ and LDH released extracellularly $(B)$.

tection was afforded by DTPA which does not enter the cell nor by $200 \mu \mathrm{M}$ zinc, a redox-inactive metal that reportedly protects beating isolated hearts (23) (data not shown).

$L D H$ release. The cessation of contractile activity is associated with alteration of membrane integrity and the leakage of cytoplasmic enzymes. To study lactate dehydrogenase (LDH) leakage, $\mathrm{H}_{2} \mathrm{O}_{2}$ was added to the cell culture and the medium was sampled for $\mathrm{LDH}$ assay. The enzymatic activity in the medium was compared with that assayed after total cell disruption and the level of extracellular activity was calculated as a fraction of the total activity. The effect of $\mathrm{H}_{2} \mathrm{O}_{2}$ on LDH leakage and the protective effect of DFO are displayed in Fig. 2 B.

Nitroxides effect. Unlike exogenously added SOD, which did not protect the cells against $\mathrm{H}_{2} \mathrm{O}_{2}$, low-molecular weight stable nitroxide radicals which can function to dismutate superoxide had a profound effect. Both five-membered (oxazolidine and pyrolidine derivatives) and six-membered (piperidine derivatives) stable nitroxides (Scheme I) were tested for their biological activity. Fig. 1 demonstrates the protective effect of $0.5 \mathrm{mM}$ Tempo and $0.5 \mathrm{mM}$ compound II against $\mathrm{H}_{2} \mathrm{O}_{2}$. Similar protection was provided by $0.5 \mathrm{mM}$ compound I, Tempol, Tempamine, and PCA (data not shown). The protective effect could have been ascribed to some reaction of the nitroxide with $\mathrm{H}_{2} \mathrm{O}_{2}$. The EPR spectrum of the nitroxide was, therefore, examined before and right after incubation with the plated cells to determine if the level of nitroxide varied during the experiment: no difference was found between the respective spectra.
No decrease in nitroxide signal was observed also when $10 \mu \mathrm{M}$ Tempol with $500 \mu \mathrm{M} \mathrm{H}_{2} \mathrm{O}_{2}$ were incubated with the cells. To examine whether nitroxides facilitated $\mathrm{H}_{2} \mathrm{O}_{2}$ removal, aliquots of the medium were taken throughout the experiment and assayed for $\mathrm{H}_{2} \mathrm{O}_{2}$ concentration. Nitroxides did not change the extracellular $\mathrm{H}_{2} \mathrm{O}_{2}$ concentration (data not shown), thus ruling out the possibility that they have a catalaselike activity. The nitroxide protective effect was dose-dependent and the minimal concentration of nitroxide required for protection increased with increasing $\mathrm{H}_{2} \mathrm{O}_{2}$ concentration (Fig. 3, Table I). Fig. 3 demonstrates the protective effect of several nitroxides on $\mathrm{H}_{2} \mathrm{O}_{2}$-induced cellular release of $\mathrm{LDH}$.

\section{Discussion}

The present results indicate that hydrogen peroxide or biologic products resulting from hydrogen peroxide impairs cell function and integrity, in agreement with previous reports that $\left[\mathrm{H}_{2} \mathrm{O}_{2}\right]>30 \mu \mathrm{M}$ is toxic to isolated rat heart (24). Contrary to catalase which removes $\mathrm{H}_{2} \mathrm{O}_{2}$, none of the nitroxides affect $\mathrm{H}_{2} \mathrm{O}_{2}$ concentration. Yet, they all protect against $\mathrm{H}_{2} \mathrm{O}_{2}$ toxicity (Figs. 1 and 3, Table $\mathrm{I}$ ). This shows that a reaction metabolite derived from $\mathrm{H}_{2} \mathrm{O}_{2}$ and not $\mathrm{H}_{2} \mathrm{O}_{2}$ itself is responsible for myocardial cell dysfunction. Further, unlike DTPA which does not enter the cell, both DFO and bipyridine, enter cells, bind intracellular metal ions (especially iron), and protect against $\mathrm{H}_{2} \mathrm{O}_{2}$. This indicates that $\mathrm{H}_{2} \mathrm{O}_{2}$-induced biological damage is mediated by cellular transition metals. Potentiation of $\mathrm{H}_{2} \mathrm{O}_{2}$-induced cytotoxicity would be anticipated if redox-active metals coordinated at critical cellular sites were to catalyze ${ }^{\circ} \mathrm{OH}$ formation. Injury inflicted in the immediate vicinity of critical targets by deleterious species would be accounted for by a mechanism in which metal binding is a prerequisite for site-specific damage. The bound metal (coordinated to biologic ligands [L]) is reducible by $\mathrm{O} \frac{\dot{2}}{2}$ or other reductants:

$\mathrm{L}-\mathrm{M}^{\mathrm{n}+}+\mathrm{O} \dot{\frac{1}{2}} \rightarrow \mathrm{L}-\mathrm{M}^{(\mathrm{n}-1)+}+\mathrm{O}_{2}$.

The reduced metal may react with $\mathrm{H}_{2} \mathrm{O}_{2}$ to form a peroxo complex (25):

$\mathrm{L}-\mathrm{M}^{(\mathrm{n}-1)+}+\mathrm{H}_{2} \mathrm{O}_{2} \rightarrow \mathrm{L}-\mathrm{M}^{(\mathrm{n}-1)+}-\mathrm{H}_{2} \mathrm{O}_{2}$,

yielding ${ }^{\circ} \mathrm{OH}$ radicals

$\mathrm{L}-\mathrm{M}^{(\mathrm{n}-1)+}-\mathrm{H}_{2} \mathrm{O}_{2} \rightarrow \mathrm{L}^{-\mathrm{M}^{\mathrm{n}}}+\mathrm{OH}^{-}+{ }^{\circ} \mathrm{OH}$

and/or be oxidized to higher oxidation states of the metal (25)

L-M $\mathrm{M}^{(\mathrm{n}-1)+}-\mathrm{H}_{2} \mathrm{O}_{2} \rightarrow \mathrm{L}-\mathrm{M}^{(\mathrm{n}+1)+}+2 \mathrm{OH}^{-}$.

According to this mechanism, the damage caused by ${ }^{\circ} \mathrm{OH}$ radicals or hypervalent metals is site-specific; therefore, scavengers
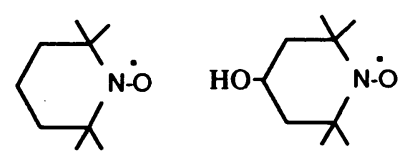

Tempol

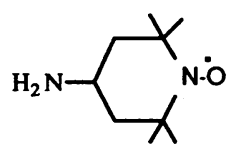

Tempamine

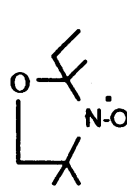

I

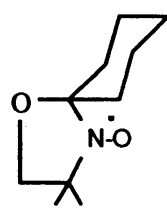

II

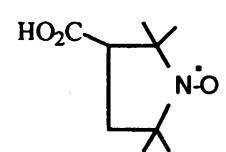

PCA

Scheme I 


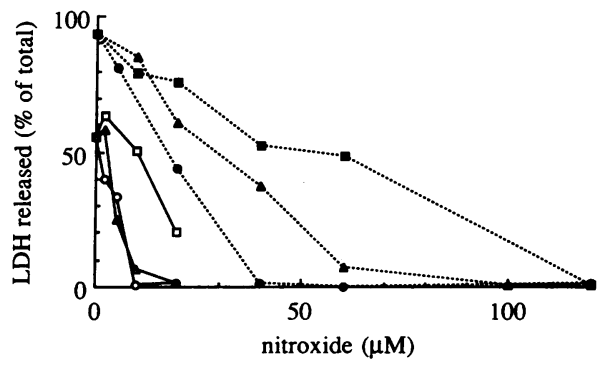

Figure 3. Dose-dependence of nitroxide protection against $\mathrm{H}_{2} \mathrm{O}_{2}$-induced $\mathrm{LDH}$ leakage from cardiomyocytes. Monolayered beating cardiomyocytes were exposed to $\mathrm{H}_{2} \mathrm{O}_{2}$ in the presence of varying concentrations of Tempol (circles), Tempo (squares), and compound II (triangles). The cultured cells were incubated for $140 \mathrm{~min}$ and the extruded LDH was determined as detailed in Methods. The extent of released LDH is presented as a fraction of the total cellular enzyme. $250 \mu \mathrm{M} \mathrm{H}_{2} \mathrm{O}_{2}$ (open symbols, solid line); $500 \mu \mathrm{M} \mathrm{H}_{2} \mathrm{O}_{2}$ (solid symbols, dashed line).

of ${ }^{\circ} \mathrm{OH}$ radicals would not be expected to provide protection. Conversely, all reagents that can remove $\mathrm{H}_{2} \mathrm{O}_{2}$ (i.e., catalase), dismutate $\mathrm{O} \dot{\frac{1}{2}}$ (i.e., $\mathrm{SOD}$ ), bind to or displace metal ions (i.e., DFO), or successfully compete for ${ }^{\circ} \mathrm{OH}$ radicals can reduce the biological injury. Considering the SOD-like activity of nitroxides $(15,16)$ and the intracellular site of the critical damage, the nitroxide-protective effect may be attributed to the removal of intracellular $\mathrm{O} \div \frac{-}{2}$ radicals. Yet, it is not necessarily proven that the nitroxides protect solely by virtue of their SOD-mimic activity, because they may also act through alternative mechanisms. Other test systems in which oxygen is not present, such as Chinese hamster cells treated with $\mathrm{H}_{2} \mathrm{O}_{2}$ in the absence of oxygen, were protected by Tempol and compound II $(17,19)$. It is possible, therefore, that nitroxides contribute to cell protection through $\mathrm{O}-\dot{2}$-independent mechanisms. Compound II and Tempo were found to oxidize chelated iron(II), and it has been proposed that they compete with $\mathrm{H}_{2} \mathrm{O}_{2}$ for the reduced metal ions (17):

Table I. Tempol Protection against $\mathrm{H}_{2} \mathrm{O}_{2}$-induced Loss of Beating of Monlayered Cardiomyocytes

\begin{tabular}{cccccc}
\hline & \multicolumn{5}{c}{$\left[\mathrm{H}_{2} \mathrm{O}_{2}\right], \mu \mathrm{M}$} \\
\cline { 2 - 6 } [Tempol] & 0 & 250 & 500 & 1000 & 2500 \\
\hline$\mu M$ & & & & & \\
0 & +++ & --- & --- & --- & --- \\
40 & +++ & +++ & --- & --- & --- \\
100 & +++ & ++- & +++ & --- & --- \\
200 & +++ & +++ & + \pm+ & - \pm+ & --- \\
400 & +++ & + \pm+ & +++ & - \pm+ & -- \\
1000 & +++ & + \pm+ & \pm++ & -++ & --- \\
2000 & +++ & +++ & \pm++ & -++ & --- \\
& & & & &
\end{tabular}

The three signs for each experimental system represent three consecutive assays of cell beating monitored 15,50 , and $105 \mathrm{~min}$ after the addition of $\mathrm{H}_{2} \mathrm{O}_{2}$. These notations represent either full effect, no effect, or partial effect. No effect: all cells in the plate are synchronically beating (+); partial effect: only few "beating microscopic fields" are operative in the plate $( \pm)$; full effect: none of the cells are beating $(-)$.

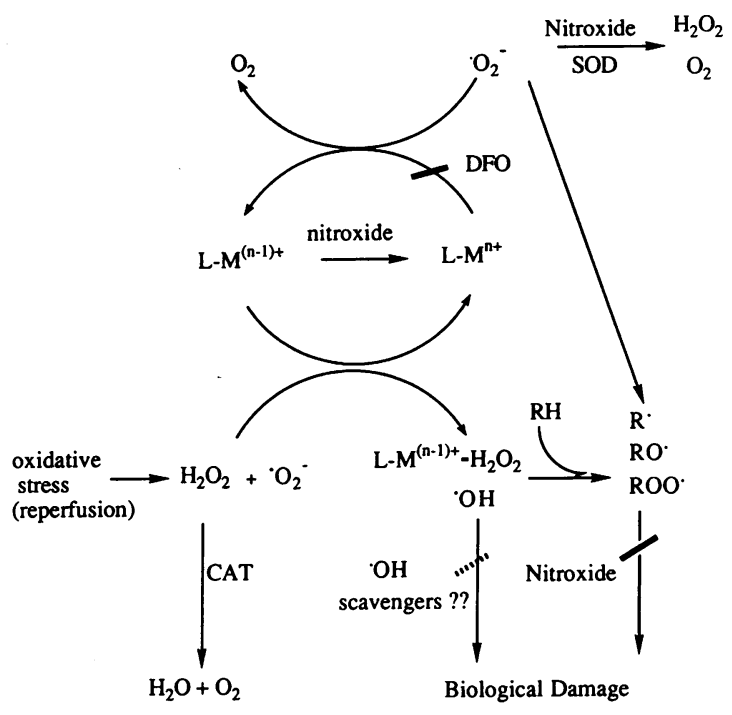

Scheme II

nitroxide $+\mathrm{H}^{+}+\mathrm{L}-\mathrm{M}^{(\mathrm{n}-1)+} \rightarrow$ hydroxylamine $+\mathrm{L}-\mathrm{M}^{\mathrm{n}+},(5)$

with a consequent inhibition of reaction 2. Fig. 3 and Table I demonstrate that higher nitroxide concentrations are needed to protect against higher $\left[\mathrm{H}_{2} \mathrm{O}_{2}\right]$. This result would support the assumption that both $\mathrm{H}_{2} \mathrm{O}_{2}$ and the nitroxide compete (reactions 2 and 5) for the same species, presumably the reduced metal (17). Previous studies indicated that nitroxides protect DNA against oxidative damage. In the present study, nitroxides protected the cardiomyocytes predominantly from $\mathrm{H}_{2} \mathrm{O}_{2}$ induced damage to the membrane (Fig. $2 \mathrm{~B}$ and Fig. 3). Moreover, the nitroxide concentration required for protection was one to two orders of magnitude lower (Fig. 3, Table I) than that necessary to protect Chinese hamster cells. Such a difference would be anticipated considering the preferential partition of nitroxides into membrane compartments, further supporting the assumption that nitroxides protect by inhibiting reaction 2 . This, however, does not exclude the possibility that nitroxides may protect through reaction with $\mathrm{O} \div$ and secondary radicals such as $\mathrm{R}^{\circ}, \mathrm{RO}^{\circ}$, or $\mathrm{ROO}$, as previously reported (26-28), terminating the propagation of radical chain reactions. Potentially, at least, nitroxides may protect by three separate mechanisms, as illustrated in Scheme II.

In conclusion, the present results show that $(a) \mathrm{H}_{2} \mathrm{O}_{2}$-induced damage to cultured cardiomyocytes results in leakage of $\mathrm{LDH}$ and loss of contractility, $(b)$ the damage, catalyzed by intracellular redoxactive metals, is not abrogated by extracellular superoxide dismutase, $(c)$ both five- and six-membered ring nitroxides protect the cells against $\mathrm{H}_{2} \mathrm{O}_{2}$ without acting as catalase-mimics, $(d)$ the nitroxides protect in a dose-dependent manner, dependent on the concentration of the $\mathrm{H}_{2} \mathrm{O}_{2}$, and $(e)$ the protective effect is attributable to removal of carbon- or oxygen-centered radicals (such as superoxide) and to reoxidation of reduced metals. Although the precise mechanisms of this protection are still only partially understood, we have demonstrated that these nitroxides protect against the damaging effects of $\mathrm{H}_{2} \mathrm{O}_{2}$ and that nitroxide derivatives could serve as novel research tools to study intracellular free radical injury in general and might find specific application in preventing ischemia/reperfusion injury. 


\section{References}

1. McCord, J. M. 1987. Oxygen-derived radicals: a link between reperfusion injury and inflammation. Fed. Proc. 46:2402-2406.

2. Zweier, J. L., J. T. Flaherty, and M. L. Weisfeldt. 1987. Direct measurement of free radical generation following reperfusion of ischemic myocardium Proc. Natl. Acad. Sci. USA. 84:1404-1407.

3. Zweier, J. L. 1988. Measurement of superoxide-derived free radicals in the reperfused heart. J. Biol. Chem. 263:1353-1357.

4. Zweier, J. L., P. Kuppusamy, and G. A. Lutty. 1988. Measurement of endothelial cell free radical generation: evidence for a central mechanism of free radical injury in postischemic tissues. Proc. Natl. Acad. Sci. USA. 85:4046-4050.

5. Chambers, D. E., D. A. Parks, G. Patterson, R. Roy, J. M. McCord, S

Yoshida, L. F. Parmley, and J. M. Downey. 1985. Xanthine oxidase as a source of

free radical damage in myocardial ischemia. J. Mol. Cell. Cardiol. 17:142-152.

6. Simpson, P. J., J. K. Mickelson, and B. R. Lucchesi. 1987. Free radical scavengers in myocardial ischemia. Fed. Proc. 46:2413-2421.

7. Hearse, D. J., A. S. Manning, J. M. Downey, and D. M. Yellon. 1986 Xanthine oxidase: a critical mediator of myocardial injury during ischemia and reperfusion? Acta Physiol. Scand. Suppl. 548:65-78.

8. Zweier, J. L., B. K. Rayburn, J. T. Flaherty, and M. L. Weisfeldt. 1987. Recombinant superoxide dismutase reduces oxygen free radical concentrations in reperfused myocardium. J. Clin. Invest. 80:1728-1734.

9. Myers, C. L., S. J. Weiss, M. M. Kirsh, and M. Shlafer. 1985. Involvement of hydrogen peroxide and hydroxyl radical in the 'oxygen paradox': reduction of creatine kinase release by catalase, allopurinol or deferoxamine, but not by superoxide dismutase. J. Mol. Cell. Cardiol. 17:675-684.

10. Ambrosio, G., J. L. Zweier, W. E. Jacobus, M. L. Weisfeldt, and J. T. Flaherty. 1987. Improvement of postischemic myocardial function and metabolism induced by administration of deferoxamine at the time of reflow: the role of iron in the pathogenesis of reperfusion injury. Circulation. 76:906-915.

11. Menasche, P., C. Grousset, Y. Gauduel, C. Mouas, and A. Piwnica. 1986. Enhancement of cardioplegic protection with the free-radical scavenger peroxidase. Circulation. 74(Suppl. III):138-144.

12. Berliner, L. J. 1976 and 1979. Spin Labeling (I and II): Theory and Applications. Academic Press, Inc., New York, N.Y. 592 and 357 pp.

13. Swartz, H. M. 1987. Use of nitroxides to measure redox metabolism in cells and tissues. J. Chem. Soc. Faraday Trans. I. 83:191-202.

14. Brasch, R. C. 1983. Work in progress: methods of contrast enhancement for NMR imaging and potential applications. Radiology. 147:781-788.
15. Samuni, A., C. Murali Krishna, P. Riesz, E. Finkelstein, and A. Russo. 1989. Superoxide reaction with nitroxide spin-adducts. Free Radical Biol. \& Med. 6:141-148.

16. Samuni, A., C. Murali Krishna, P. Riesz, E. Finkelstein, and A. Russo. 1988. A novel metal-free low molecular weight superoxide dismutase mimic. $J$. Biol. Chem. 263:17921-17924.

17. Mitchell, J. B., A. Samuni, C. Murali Krishna, W. G. Degraff, M. S. Ahn, U. Samuni, and A. Russo. 1990. Biologically active metal-independent superoxide dismutase mimics. Biochemistry. 29:2902-2807.

18. Nilsson, U. A., L.-I. Olsson, G. Carlin, and A.-C. Bylund-Fellenius. 1989. Inhibition of lipid peroxidation by spin labels: relationships between structure and function. J. Biol. Chem. 264:11131-11135.

19. Samuni, A., J. B. Mitchell, W. DeGraff, C. Murali Krishna, U. Samuni, and A. Russo. 1991. Nitroxide SOD-mimics: modes of action. Free Radical Res. Commun. In press.

20. Keana, J. F. W., S. B. Keana, and D. Beetham. 1967. A new versatile ketone spin label. J. Am. Chem. Soc. 89:3055-3056.

21. Link, G., A. Pinson, and C. Hershko. 1985. Heart cells in culture: a model of myocardial iron overload and chelation. J. Lab. Clin. Med. 106:147-153.

22. Wroblewski, F., and J. S. LaDue. 1955. Lactic dehydrogenase activity in blood. Proc. Soc. Exp. Biol. Med. 90:210-213.

23. Powell, S., P. Saltman, G. Uretzky, and M. Chevion. 1990. The effect of zinc on reperfusion arrhythmias in the isolated perfused rat heart. Free Radical Biol. \& Med. 6:33-46.

24. Shattock, M. J., A. S. Manning, and D. J. Hearse. 1982. Effects of hydrogen peroxide on cardiac function and post-ischemic functional recovery in the isolated 'working' rat heart. Pharmacology (Basel). 24:118-122.

25. Masarwa, M., H. Cohen, D. Meyerstein, D. L. Hickman, A. Bakac, and J. H. Espenson. 1988. Reactions of low-valent transition-metal complexes with hydrogen peroxide. Are they "Fenton-like" or not? 1 . The case of $\mathrm{Cu}_{a q}^{+}$and $\mathrm{Cr}_{\mathrm{aq}}{ }^{2+}$ J. Am. Chem. Soc. 110:4293-4297.

26. Blough, N. V. 1988. Electron paramagnetic resonance measurements of photochemical radical production in humic substances. 1. Effects of $\mathrm{O} 2$ and charge on radical scavenging by nitroxides. Environ. Sci. \& Technol. 22:77-82.

27. Chateauneuf, J., J. Lusztyk, and K. U. Ingold. 1988. Absolute rate constants for the reactions of some carbon-centered radicals with 2,2,6,6-tetramethylpiperidine- $N$-oxyl. J. Org. Chem. 53:1629-1632.

28. Robbins, W. K., and R. H. Eastman. 1970. Photodecarbonylation in solution. II. Trapping of intermediates in the photolysis of dibenzyl ketone. $J$. Am. Chem. Soc. 92:6077-6079. 